\section{Poor communication blamed for delays to US visas}

Geoff Brumfiel, Washington

Foreign students and scientists coming to the United States are suffering big delays caused by immigration restrictions, a congressional report has confirmed.

The report, which is set for release this week, tracked 71 science students and scholars who underwent security screenings in the wake of the 11 September 2001 terrorist attacks. It found that they waited a mean period of 67 days for their visas - well above the state department's 30-day target.

"The report gives weight to what a lot of us were guessing at from anecdotal evidence," says Wendy White, who works on international issues at the National Academy of Sciences.

The House Committee on Science commissioned the study last year from the Government Accounting Office (GAO), after hearings showed that foreign scientists were facing lengthy visa delays (see Nature 422, 457; 2003).

The delays are particularly bad for scientists from countries such as India, China and Russia, who must undergo frequent interagency security reviews that involve the FBI, the CIA and the Department of Homeland Security.

The GAO says that most delays are caused by communication lapses, either between these departments or within the state department, which administers the embassies and consulates. It can take up to two-and-a-half months for a request to get from an embassy to the FBI, and as long as 45 days for the FBI's clearance to reach the state department, it says.

The report also says that consular staff "lack guidance" on when to apply security reviews, and receive little feedback on whether they are providing the right information about an applicant.

Stuart Patt, a spokesman for the state department, defended its position, saying that it was hiring new consular officers and providing some scientific training for existing ones. He added that the department would soon install a new computer system, which should aid internal communication.

But White's office has received more than 1,100 complaints from foreign scientists since last June. She says that the state department's plans will help to reduce delays, but that much more remains to be done. "The mechanics of the process are getting better," she says, "but the overall feeling that the United States is no longer a welcoming place persists."

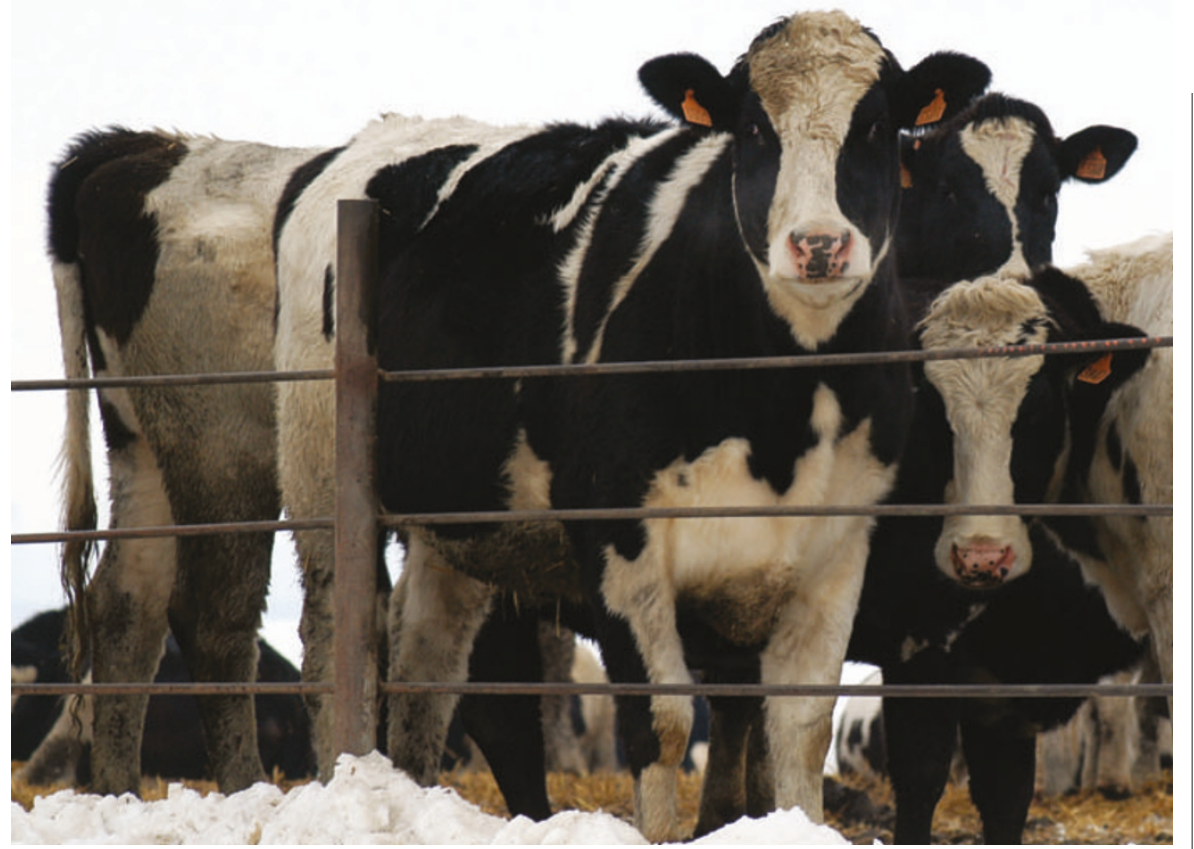

Still reeling: the US effort to monitor mad cow disease has yet to find its feet, according to congressmen.

\title{
Mad cow's standing puts downer on testing strategy
}

\section{Erika Check, Washington}

The US Department of Agriculture (USDA) is facing growing pressure from Congress to overhaul its surveillance regime for mad cow disease.

A powerful congressional committee says that the agriculture secretary, Ann Veneman, gave the public wrong information about the first mad cow found in the United States in December. Veneman said at the time that the cow had been targeted for testing because it was a 'downer' - an animal that arrived at the slaughterhouse too sick to walk (see Nature 427, 5; 2004).

But two employees at the slaughterhouse in Washington state where the animal was killed, and the hauler who took the cow there, have all told congressional investigators that the cow wasn't a downer at all. The revelation seems to undermine Veneman's assertion that the department's existing focus on testing obviously sick animals was vindicated by the cow's detection.

In an unusual bipartisan move, the top Republican and the senior Democrat on the House Committee on Government Reform wrote to Veneman on 18 February, urging her to resolve the issue.

According to the letter, the co-manager of the slaughterhouse faxed a USDA office on 6 January to state that the mad cow was not a downer. He said that the animal was healthy, and had been tested under a contract whereby the USDA paid the slaughterhouse $\$ 10$ per cow for test samples.

The revelations could force the agriculture department to change its current plan to test just 40,000 cows for mad cow disease this year. "If the new information is accurate, USDA's surveillance programme may need to be significantly expanded," wrote congressmen Tom Davis (Republican, Virginia) and Henry Waxman (Democrat, California) in their letter. "The new information also raises questions about USDA's credibility."

Earlier this month, an international review team chaired by Ulrich Kihm, Switzerland's chief veterinary officer, recommended that the USDA expand its programme to test all cows over 30 months old as well as some younger, healthy animals (see Nature 427, 575; 2004). In their letter, the congressmen agreed: "We believe USDA should either follow the recommendations of these independent experts and expand mad cow testing substantially or provide a compelling reason for not doing so," they wrote.

And while the agriculture department seemed reluctant to accept that advice at first, its position appears to be becoming more flexible. "Everything is in flux right now," says Jim Rogers, a spokesman for the USDA's Animal and Plant Health Inspection Service. "Last I heard we were on target for testing 40,000 animals a year, but that could change, for sure."

Rogers says that the agriculture department is also trying to figure out how to find and test downed animals, now that they are excluded from the food supply and will no longer be tested at slaughterhouses. He added that the department's inspector general would investigate the allegations that the first mad cow was not actually a downer. 